\title{
Successful Treatment of Dwarfism and Hypogonadism after Total Removal of Craniopharyngioma
}

\author{
Tatsuya Kobayashi, Jun Yoshida, Naoki Kageyama, Osamu Mori* \\ and Masamichi OGAWA*
}

Departments of Neurosurgery and *Pediatrics, School of Medicine, Nagoya University, Nagoya

\begin{abstract}
A case of successful treatment of child craniopharyngioma is reported. The tumor was totally removed seven years ago and the patient's height became normalized by human growth hormone (HGH) therapy lasting for $21 / 2$ years. Completed development of his sexual characteristics and induction of spermatogenesis resulted from a combination therapy with human chorionic gonadotropin (HCG) and human menopausal gonadotropin (HMG).
\end{abstract}

Key words: craniopharyngioma, total removal, dwarfism, HGH therapy, hypogonadism, HCG-HMG therapy

\section{Introduction}

The treatment for craniopharyngiomas is still controversial. ${ }^{4,6,8)}$ However, there has been an increasing number of reported cases with long survival after extensive removal of the tumor and other multimodal therapies. ${ }^{7,10)}$ Further problems afficting such children are dwarfism ${ }^{1,16)}$ and hypogonadism, ${ }^{11)}$ which are almost always accompanied with craniopharyngioma.

We are reporting a successful case, with completed development of all sexual characteristics and induction of spermatogenesis by gonadotropin treatment, whose tumor was totally removed 7 years ago and his height became normalized as a result of human growth hormone $(\mathrm{HGH})$ therapy lasting for 2 and a half years.

\section{Case Report}

The patient, a 13-year-old boy was admitted because of his short stature, nausea and vomiting on September 11, 1972. His short stature was noticed at the time of his entrance to elementary school in 1966. He experienced attacks of headache once or twice a month and had noticed a gradual loss of his visual acuity, which required him to wear glasses since 1970. Three months before admission, his headaches in-

Received July 9, 1984; Accepted November 5, 1984

creased in severity and frequency (three times a week) and were sometimes accompanied with vomiting.

On admission, his height was $130.3 \mathrm{~cm}$ and his weight $28.3 \mathrm{~kg}$. His sensorium was slightly lethargic. His temperature did not rise above $35.5^{\circ} \mathrm{C}$. His visual acuity was corrected to the normal range by glasses. Mild papilledema was found by fundoscopy. Plain craniogram showed suprasellar calcification (Fig. 1) and his bone age was estimated as that of a 10-yearold boy. Carotid angiography revealed an elevated $A_{1}$ portion and unrolling of the anterior cerebral artery. An air study showed filling defects of the anterior third ventricle and the chiasmatic cistern. Hormone assay revealed low or no response of the $\mathrm{GH}$ to the insulin tolerance test and arginine test. Serum FSH and $\mathrm{LH}$ were low and did not respond to LH-RH. Serum TSH and plasma ACTH were in the subnormal range. There was no diabetes insipidus. Blood picture and serum chemical studies were within normal range.

The patient was referred to our department for treatment of the suprasellar mass. Right frontotemporal craniotomy was performed on December 4, 1972. The cystic mass was totally removed through the subfrontal approach. The pituitary stalk was sacrificed because of tumor invasion. The pathological diagnosis was adamantinomatous craniopharyngioma. The postoperative course was uneventful except for mild diabetes insipidus, which was controlled by antidiuretics. The patient was discharg- 


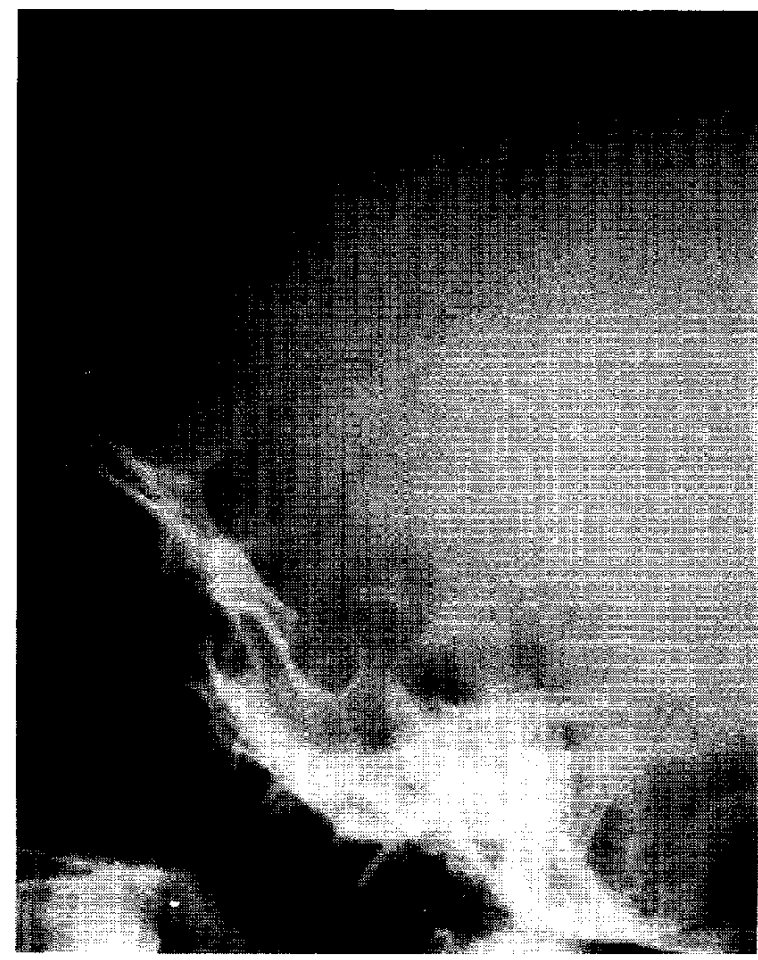

Fig. 1 Plain skull film on admission showing irregullar calcification at suprasellar region and no sellar enlargement.

ed on February 4, 1973 with hormone replacement therapy with steroid (Hydrocortone; $20 \mathrm{mg} /$ day), thyroid hormone (Thyradine S; $100 \gamma /$ day) and antidiuretics (Fruitran; $2 \mathrm{mg} /$ day and Diabenese; $100 \mathrm{mg} /$ day). No other treatment was given until March, 1975, when he was chosen as a candidate for the use of $\mathrm{HGH}$ for secondary dwarfism. He was 15 years old and his height at that time was 143.5 $\mathrm{cm}$ (below $-2 \mathrm{SD}$ of the mean growth curve for Japanese boys). He was given 8 units of $\mathrm{HGH}$ (Crescormone) a week for 2 years and 4 months. At this time $\mathrm{HGH}$ treatment was terminated, because his height reached $156.6 \mathrm{~cm}$. There was a further, natural increase in his height of $7.2 \mathrm{~cm}$ in 2 years and 8 months, and when he was 19 years old his height reached $163.8 \mathrm{~cm}$ (Fig. 2).

Because the patient showed no secondary sexual characteristics and there was no evidence of tumor recurrence according to CT scan (Fig. 3), gonadotropin treatment was started in March, 1980 for his hypogonadism. At this time, his serum testosterone level was $0.2 \mathrm{ng} / \mathrm{ml}$, and serum LH and FSH peak levels to LH-RH test were 5.0 and $2.0 \mathrm{~mJ} . \mathrm{U} . / \mathrm{ml}$, respectively (Table 1). This treatment consisted of two steps; first, 3,000 units of human chorionic

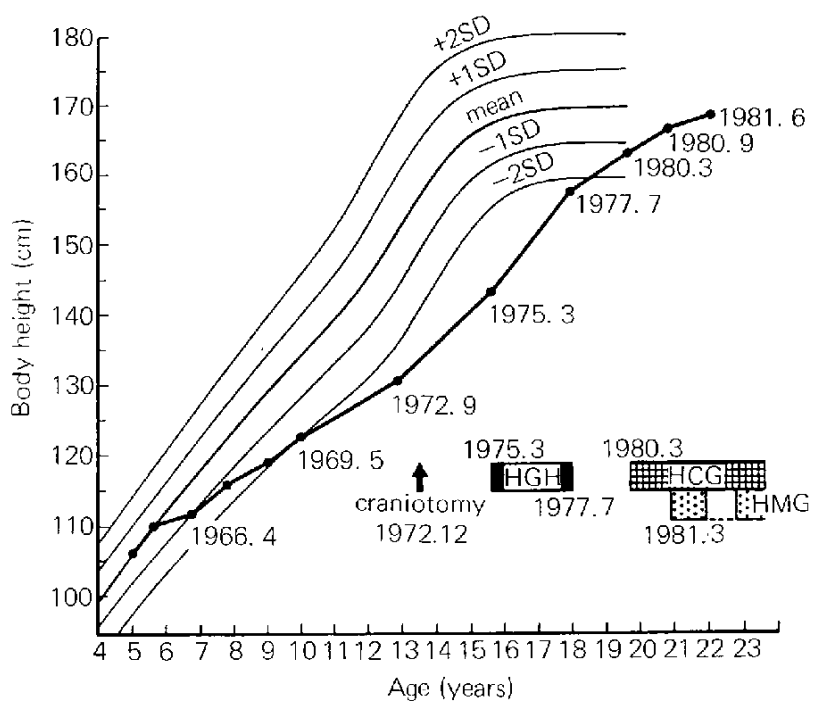

Fig. 2 Height curve before, during and after $\mathrm{HGH}$ treatment. Patient's height at different times is plotted on the mean height curve of normal Japanese boys. The height became normalized after total removal of tumor followed by $\mathrm{HGH}$ treatment. Gonadotropin therapy was initiated when patient's height reached $163.8 \mathrm{~cm}$.

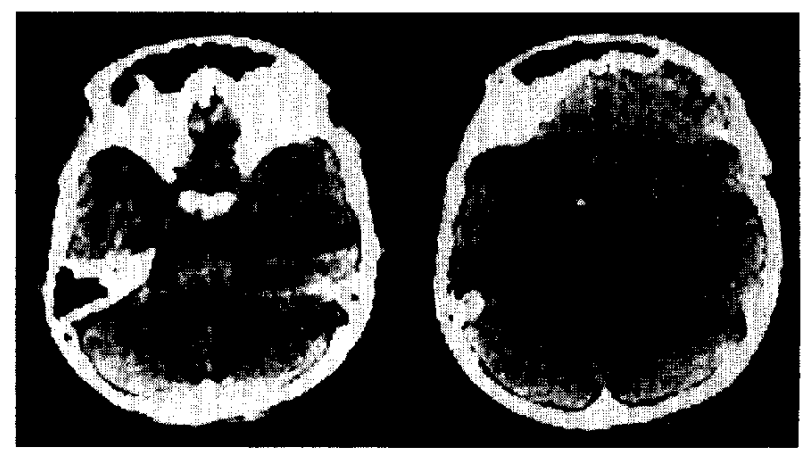

Fig. $3 \mathrm{CT}$ scan before gonadotropin treatment showing no suprasellar mass nor tumor calcification.

gonadotropin (HCG, Pregnine) were given intramuscularly three times a week. After induction of secondary sexual characteristics for a year, 75 units of human menopausal gonadotropin (HMG, Humegone) were given three times a week for 9 months in addition to HCG. After 6 months, another HMG regimen was given until March, 1983. The effectiveness of this treatment has been judged by the following parameters (Table 1); the secondary sexual characteristics were evaluated by the volume of the testis (orchidometry), length and diameter of the 
Table 1 HCG-HMG treatment for hypopogonadism in craniopharyngioma*

\begin{tabular}{|c|c|c|c|c|c|c|c|c|c|}
\hline \multirow{2}{*}{ 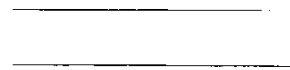 } & \multirow[b]{2}{*}{1980.3} & \multirow[b]{2}{*}{9} & \multirow[b]{2}{*}{1981.1} & & \multirow[b]{2}{*}{6} & \multirow[b]{2}{*}{1982.1} & \multirow[b]{2}{*}{2} & \multirow[b]{2}{*}{7} \\
\hline & & & & 3 & 4 & & & & \\
\hline \multicolumn{10}{|l|}{ Penis } \\
\hline Length $(\mathrm{cm})$ & 3.2 & 4 & 4 & 4.5 & & 6 & 6.3 & 6.5 & 6 \\
\hline Circum. (cm) & & & & 2.3 & & 8 & 7.3 & 8 & 7.9 \\
\hline Testis $(\mathrm{ml})$ & 2 & 3 & 4 & 4 & 5 & $6-8$ & 8 & 6,5 & 5 \\
\hline \multicolumn{10}{|l|}{ Hair } \\
\hline Pubic & - & - & $I^{\circ}$ & II $^{\circ}$ & & $\mathrm{II}-\mathrm{III}^{\circ}$ & $I V^{\circ}$ & & IV $^{\circ}$ \\
\hline Armpit & - & - & - & & & \pm & $\mathrm{I}^{\circ}$ & & $\mathrm{II}^{\circ}$ \\
\hline Erection & - & - & & \pm & + & & $H$ & & \\
\hline Ejaculation & - & - & & - & & & - & & \\
\hline Change of voice & - & - & - & - & + & & & & + \\
\hline $\begin{array}{l}\text { Testosterone } \\
\text { (ng/ml) }\end{array}$ & 0.2 & 1.53 & & 9.52 & & 8.25 & & 9.8 & 6.7 \\
\hline $\mathrm{LH}(\mathrm{mI} . \mathrm{U} . / \mathrm{ml})$ & 5.0 & 3.0 & & & & & & & \\
\hline FSH $(\mathrm{mI} . \mathrm{U} / \mathrm{ml})$ & 2.0 & 2.0 & & & & & & & \\
\hline Body height $(\mathrm{cm})$ & 163.8 & 164.3 & & 166 & & 168 & & 169.1 & \\
\hline
\end{tabular}

${ }^{*}$ The effectiveness of gonadotropin treatment has been judged by the changes of secondary sexual characteristics, periodic hormone assay and biopsy of testicular gland.

penis, maturation of the pubic or armpit hair (Tanner's grading). Hormone assays were made for serum testosterone, LH and FSH. Spermatogenesis and maturation of testicular glands were assessed by biopsy of the testis.

Although the secondary sexual characteristics had been completely absent at the initiation of this treatment (Fig. 4A), the pubic hair, volume of testis, the size of penis increased during a year of HCG treatment and just before the HMG treatment. By the combination of $\mathrm{HCG}$ and HMG treatments for 9 months, further maturation of the sexual characteristics such as erection of the penis and change of voice took place. The serum testosterone level became normalized within a month of HMG treatment and was maintained at a normal level thereafter. The completion of secondary sexual characteristics has been achieved during the second administration of HMG treatment (Fig. 4B). A biopsy of the testis before treatment showed an immature narrow tubular structure without identifiable Sertoli and Leydig cells (Fig. 4C). After the treatment, considerable increases in the tubular diameter, maturation of the germinal cell content, such as Sertoli cells and gonocytes and matured fibrillary matrix with Leydig cells have been demonstrated (Fig. 4D). Spermatogenesis has now been initiated by the maturation of the testis.

This patient is now 24 years old, working as a businessman and living a useful life.

\section{Discussion}

The effectiveness of $\mathrm{HGH}$ treatment for primary pituitary dwarfism has been established and more than $90 \%$ of the cases have been successfully treated. ${ }^{16)}$ However, there have been a few reports on the effectiveness of $\mathbf{H G H}$ for secondary dwarfism, due to craniopharyngioma ${ }^{1,16)}$ or other intracranial tumors. ${ }^{16)}$ Since 1975 , we have been using HGH in eleven cases whose tumors had been controlled by various treatments for a long time and yet who satisfied the following diagnostic criteria proposed by the study group of pituitary dwarfism in Japan: 1) a height below $-2 \mathrm{SD}$ of the mean height curve, 2) a growing rate of less than $4 \mathrm{~cm}$ per year, 3) before closure of the epiphyseal line and a bone age of less than $75 \%$ of the chronological age, 4) loss or diminished secretion of HGH. As a result of HGH therapy, all except one showed an increased annual growth rate that was twice that of the pretreatment value. However, there are some problems regarding $\mathrm{HGH}$ treatment for craniopharyngioma patients. ${ }^{2)}$ There is a tendency of a decreasing annual growth ratio as the duration of the treatment is prolonged. This may be due to $\mathrm{HGH}$ antibody formation. ${ }^{3)}$ Other factors influencing the results are shortage of dosis, ${ }^{97}$ effect of steroids ${ }^{14)}$ used simultaneously and the possibility of tumor regrowth.

The replacement therapy for gonadal hormones has been more complicated and difficult. Testosterone or LH-RH had been used for these purposes, 

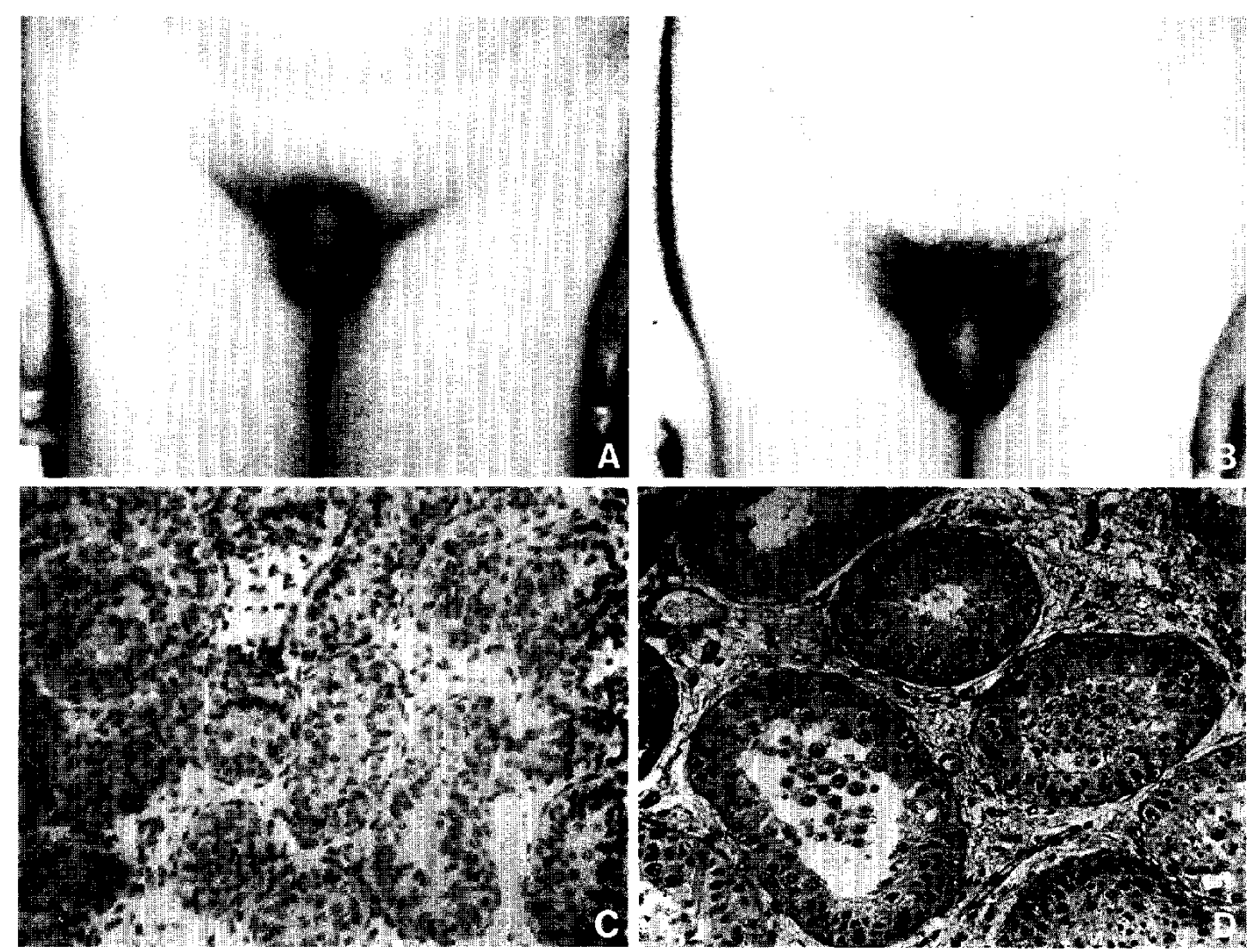

Fig. 4 Maturation of sexual organs by gonadotropin therapy. A: Before gonadotropin treatment (at age of 19), no secondary sexual characteristics were found regarding the size of penis, volume of testis and pubic hair. B: The second sexual characteristics were completed by HCG-HMG therapy. $C:$ Biopsy of the testis shows immature tubular structures and no Sertoli cells nor Leydig cells were identified before treatment. D: After HCG-HMG treatment, increase in the tubular diameter and maturation of germinal cell contents are found. Evidence of early spermatogenesis became manifested.

but the results were not satisfactory. ${ }^{9,13)}$ HCG-HMG therapy has been developed for the treatment of hypogonadotropic hypogonadistic males ${ }^{5,15)}$ and fewer numbers of successful cases have been reported in the primary or secondary conditions. ${ }^{11-13)}$ The rationale of this treatment is to stimulate the Sertoli cells by $\mathrm{HCG}$, which has $\mathrm{LH}$ effects to induce secretion of testosterone, and then to achieve spermatogenesis by HMG, which has FSH effects. ${ }^{5,9.15)}$ It is not easy to evaluate whether this regimen is the best for hypogonadism of craniopharyngioma. Lytton and Kase $^{(1)}$ reported a case of a eunuchoid male with craniopharyngioma whose testicular size increased and who had an early stage of spermatogenesis induced by HCG-HMG treatment. Johnsen ${ }^{\text {s }}$ and Steinberger ${ }^{15)}$ stated separately that a combined therapy with HCG and HMG is necessary for spermatogenesis in hypogonadotropic hypogonad- ism. This is the first adolescent case of a successful completion of secondary sexual characteristics and induction of spermatogenesis by HCG-HMG therapy after the total removal of craniopharyngioma and restoration of normal height by $\mathrm{HGH}$ treatment.

It has to be established in the future whether any maintenance regimen is necessary after the induction of spermatogenesis or if there is any safe and possible treatment for female hypogonadism. We hope that an ever-increasing number of cases with craniopharyngioma will benefit from these multimodal therapies.

\section{References}

1) Burns EC, Tanner JM, Preece MA, Cameron N: Growth hormone treatment in children with craniopharyngioma: Final growth status. Clinical 
Endocrinology 14: 587-595, 1981

2) Costin G, Kogut MD, Phillips LS, Daughaday $W_{H}$ : Craniopharyngioma: The role of insulin in promoting postoperative growth. J Clin Endocrinol Metab 42: 370-379, 1976

3) Frasier SD, Smith $J_{I}$ FG: Antibodies to human growth hormone. Amer $J$ Dis Child 112: 383-388, 1966

4) Hoffman HJ, Hendrick EB, Humphreys RP, Buncic JR, Armstrong DL, Jenkin RDT: Management of craniopharyngioma in children. $J$ Neurosurg $47: 218-$ 227,1977

5) Johnsen SG: A study of human testicular function by the use of human menopausal gonadotrophin and of human chorionic gonadotrophin in male hypogonadotrophin eunuchoidism and infantilism. Acta Endocr (Kobenhavn) 53: 315-341, 1966

6) Kahn EA, Gosch HH, Seeger JF, Hicks SP: Fortyfive years experience with craniopharyngiomas. Surg Neurol 1: 5-12, 1973

7) Kobayashi $T$, Kageyama N, Ohara K: Internal irradiation for cystic craniopharyngioma. $J$ Neurosurg 55: 896-903, 1981

8) Kobayashi T, Kageyama N, Yoshida J, Shibuya N, Yonezawa T: Pathological and clinical basis of the indications for treatment of craniopharyngiomas. Neurol Med Chir (Tokyo) 21: 39-47, 1981

9) Krabbe S, Shakkebaek HE: Gonadotropin-releasing hormone (LH-RH) and human chorionic gonadotropin in the treatment of two boys with hypogonadotrophic hypogonadism. Acta Paediatr Scand 66: $361-365,1977$

10) Laws Jr ER: Transsphenoidal microsurgery in the management of craniopharyngioma. $J$ Neurosurg 52: $661-666,1980$

11) Lytton B, Kase N: Effects of human menopausal gonadotrophin on a eunuchoidal male. New Eng $J$ Med 274: 1061-1064, 1966

12) Mancini RE, Seiguer AC, Perez-Lloret A: Effect of gonadotropins on the recovery of spermatogenesis in hypophysectomized patients. I Clin Endocr 29: 467478, 1969

13) Mortimer $\mathrm{CH}$, McNeilly AS, Fisher RA, Murray MAF, Besser GM: Gonadotrophin-releasing hormone therapy in hypogonadal male with hypothalamic or pituitary dysfunction. Brit Med $J$ 14: 617-621, 1974

14) Preece MA: The effect of administered corticosteroid on the growth of children. British Postgraduate Medical Journal 52: 625-630, 1976

15) Steinberger E: Hormone control of mammalian spermatogenesis. Physiol Rev 51: 1-22, 1971

16) Tanner JM, Whitehouse RH, Hughes PCR, Vince EP: Effect of human growth hormone treatment for 1 to 7 years on growth of 100 children, with growth hormone deficiency, low birthweight, inherited smallness, Turner's syndrome, and other complaints. Arch Dis Child 46: 745-782, 1971

Address reprint requests to: T. Kobayashi, M.D., Department of Neurosurgery, School of Medicine, Nagoya University, 65 Tsurumai-cho, Showa-ku, Nagoya 466, Japan. 